\title{
Czy RIO chronią samorząd terytorialny, czy ograniczają jego samodzielność finansową?
}

\begin{abstract}
Streszczenie
Celem artykułu jest analiza funkcji kontrolnej państwa nad działalnością samorządu terytorialnego w zakresie spraw finansowych. Przedstawiona analiza jest oparta na danych empirycznych Regionalnych Izb Obrachunkowych (RIO), które są specjalnym organem stworzonym do kontroli i nadzoru w zakresie finansów samorządowych. Zwraca się uwagę na kwestię samodzielności finansowej oraz na to, jak wpływają na nią zewnętrzna kontrola i nadzór ze strony państwa, ponieważ zarówno zbyt silna, jak i zbyt słaba kontrola mają negatywne konsekwencje dla rozważnego dysponowania środkami pieniężnymi przez władze samorządowe. Badania wskazały na zmniejszenie się ilości naruszeń prawa ze strony jednostek samorządu terytorialnego w zakresie spraw finansowych, jednak nadal istnieją przykłady nieefektywnego i nieracjonalnego wykorzystania środków przez władze jednostek samorządu terytorialnego (jst), które, mimo że nie są sprzeczne z prawem, negatywnie wpływają na ich samodzielność finansową oraz w konsekwencji na wykonywanie zadań publicznych. Na zakończenie artykułu proponowane są możliwe sposoby rozwiązania wskazanych problemów.
\end{abstract}

Słowa kluczowe: samorząd terytorialny, nadzór i kontrola finansowa, samodzielność finansowa, Regionalne Izby Obrachunkowe

\section{Do RACs Protect Local Self-Government or Restrict Its Financial Independence?}

\begin{abstract}
The aim of the article is to analyse the state control function over the activity of local self-governments in the field of their finances. The analysis is based on empirical data of the Regional Accounting Chambers (RACs), which is a special body created for control and supervision in the field of local government finances. Attention is paid to the question of financial independence of the local powers and how it is influenced by the state's
\end{abstract}


external supervision. In this context both too strong and too weak control has negative consequences for prudent funds usage by local government. The research indicates a decrease in law infringement by local authorities in the financial sphere. However, there are still cases of inefficient and irrational budget usage by local powers, which does not contradict the law, yet exerts a negative impact on their financial independence and performance of public tasks. Possible solutions of the indicated problems are outlined at the end of the article.

Keywords: local self-government, supervision and financial control, financial independence, regional accounting chambers

W 1990 r. Polska rozpoczęła reformę samorządu terytorialnego, co umożliwiło społecznościom lokalnym zarządzanie zasobami oraz rozwiązywanie problemów lokalnych na najniższym poziomie. Został zbudowany skuteczny system samorządu, który pozwala obywatelom otrzymywać potrzebne usługi publiczne na poziomie lokalnym i regionalnym.

Ważnym aspektem realizacji działań publicznych jest zapewnienie i ochrona prawna samodzielności samorządów terytorialnych przez państwo. Sama samodzielność odróżnia samorząd terytorialny od innych władz publicznych. Niezależność organów samorządowych od centralnej władzy jest jednym z czynników, który umożliwia zarządzanie dopasowane do konkretnej społeczności lokalnej w jak najlepszy sposób. Taka samodzielność w dużym stopniu opiera się na samodzielności finansowej. Samorządy powinny mieć określoną swobodę w zakresie prowadzenia gospodarki finansowej, w tym trwałe źródła dochodów, które nie będą zależały od transferów $\mathrm{z}$ budżetu państwa.

Samodzielność finansowa jest bardzo ważnym elementem dla rozwoju samorządu terytorialnego. Bez niej wykonywanie zadań publicznych oraz funkcji samorządów jest bardziej skomplikowane i ograniczone. W przypadku braku samodzielności finansowej zwiększa się zależność jst od państwa oraz rosną liczba zaciąganych kredytów i pożyczek oraz poziom zadłużenia. Wpływa to w szczególności na zahamowanie wzrostu gospodarczego terenu i infrastruktury społecznej, w skrajnych przypadkach na ich stagnację. W takiej sytuacji wzrasta liczba dotacji i subwencji państwowych, co zasadniczo narusza zasadę decentralizacji, w tym finansowej. Dlatego wysoki poziom samodzielności finansowej powinien stanowić priorytet $\mathrm{w}$ zarządzaniu władz samorządowych.

Samodzielność finansowa jednostek samorządu terytorialnego nie jest stanem niezmiennym. Jest ona ograniczana na etapie układania prawa (np. uregulowanie kształtowania dochodów i wydatków), jak i przy jego stosowaniu (np. nadzór nad 
działalnością finansową). Ograniczenia stawiane jst w zakresie zadłużania i poziomu deficytu budżetowego $z$ jednej strony negatywnie wpływają na samodzielność finansową tych jednostek, natomiast $\mathrm{z}$ drugiej strony chronią je przed wysokim poziomem długu i związanymi z nim skutkami, co chroni samodzielność finansową jst.

Mając samodzielność wykonawczą i prawotwórczą, samorząd terytorialny w polskim systemie ustawodawczym nie jest organizacją autonomiczną. Jego samodzielność polega na dokładnym określeniu, kiedy oraz w jakich formach organy państwa mogą ingerować w sferę zabronioną dla samodzielnego działania organów samorządu terytorialnego (Antkowiak, 2011). Podobnie wkraczanie w działalność jst możliwe jest tylko i wyłącznie w formie kontroli i nadzoru, zgodnie z ustawą w sposób nienaruszający samodzielności samorządów terytorialnych (Konstytucja..., 1997).

Nadzór i kontrola finansowa ze strony państwa odgrywają ważną rolę w zapewnieniu stabilności finansowej państwa i w szczególności samorządów terytorialnych. Jeśli wykonanie budżetów jest poprawne, zgodne z przepisami, środki publiczne wydawane są racjonalnie na spełnienie potrzeb społeczności lokalnych i rozwój terenu, wtedy następuje poprawa i rozwój gospodarki oraz społeczno-ekonomicznych warunków życia. Przy niewłaściwym stopniu rozwoju systemu kontroli finansowej ze strony państwa zwiększa się możliwość wystąpienia socjalnych dysfunkcji, np.: niskiego stopnia wykonania zadań publicznych przez samorząd terytorialny, wystąpienia lub wzrostu istniejącej korupcji w organach samorządowych, zbyt powolnego rozwoju dobrobytu danego terenu, deficytu budżetu czy nieefektywnego wykorzystania zasobów publicznych.

$\mathrm{W}$ artykule zastosowano podejście instytucjonalne dla analizy kontroli finansowej nad działalnością jst. Za pomocą metody funkcjonalnej przeprowadzono analizę działalności instytutów w obszarze kontroli finansowej w zakresie spraw budżetowych jst. W związku z tym, że instytuty kontroli i nadzoru finansowego odgrywają istotną rolę w funkcjonowaniu władz samorządowych, zakłada się, że mają one istotny wpływ na ich samodzielność finansową. Kontrola i nadzór finansowy tworzą możliwość poprawy efektywności gospodarowania środkami publicznymi na poziomie poszczególnych jednostek, a przecież z drugiej strony, przy zbyt dużej kontroli, można wpłynąć negatywnie na stopień samodzielności finansowej jst.

\section{NIK i RIO}

Do instytutów kontroli i nadzoru finansowego państwa należą Najwyższa Izba Kontroli (NIK) oraz Regionalne Izby Obrachunkowe (RIO). NIK jest naczelnym organem kontroli państwowej w Polsce, który podlega Sejmowi i został utworzony 
w 1919 r. Izba przeprowadza kontrolę różnych instytucji: wszystkich organów administracji rządowej, NBP, osób prawnych, jednostek samorządu terytorialnego. Bada wszystkie obszary, w które zaangażowane są publiczne pieniądze lub majątek. Działalność tych instytucji oceniana jest pod względem czterech kryteriów: legalności, gospodarności, celowości i rzetelności. Jednak NIK nie może kontrolować jednostek samorządu terytorialnego pod względem celowości ich działań (Ustawa... 1994, 2007) - byłoby to ograniczanie ich samodzielności w zakresie planowania i wykonywania zadań publicznych.

NIK sprawdza w kontrolowanych jednostkach przede wszystkim wykonanie budżetu oraz realizację ustaw i innych aktów prawnych w zakresie działalności finansowej, gospodarczej i organizacyjno-administracyjnej (Ibidem, art. 3).

Jednak NIK nie ma obowiązku prawnego prowadzenia kontroli działalności samorządów terytorialnych i nie zastępuje organów, które odpowiedzialne są za nadzór nad działalnością samorządów. Kontrola NIK dotyczy budżetu jst w części związanej z realizacją budżetu państwa. Najczęściej do takiej kontroli należą: realizacja projektów, których koszty pokrywane są ze środków Unii Europejskiej; korzystanie z dotacji celowych; nadanie i ocena dotacji udzielanych jst spoza sektora finansów publicznych; zarządzanie zasobem nieruchomości jst; stan i struktura ich długu.

Po reformie samorządowej w 1990 r. powstał nowy organ kontroli i nadzoru nad jednostkami samorządu terytorialnego w zakresie finansów (budżetu) i zamówień publicznych - Regionalne Izby Obrachunkowe. RIO są jedynym organem prowadzącym taką działalność nadzorczą oraz kontrolną w stosunku do jednostek samorządu terytorialnego.

RIO działają od 1993 r. i zostały wyznaczone ustawą z 7 października $1992 \mathrm{r}$. o regionalnych izbach obrachunkowych. Nowelizacją z 20 sierpnia 1997 r. utworzona została reprezentacja izb z terenu całego kraju w postaci Krajowej Rady Regionalnych Izb Obrachunkowych. Spośród powołanych w 1992 r. siedemnastu Regionalnych Izb Obrachunkowych - po zmianach wprowadzonych przez reformę administracyjną - funkcjonuje obecnie szesnaście ${ }^{1}$.

RIO nie są elementem systemu organizacyjnego samorządu terytorialnego, lecz specjalnie powołaną instytucją państwową. Prowadzą kontrolę zewnętrzną i nadzór organów oraz jednostek samorządu terytorialnego w zakresie wyłącznie spraw finansowych i zamówień publicznych.

Podstawowym kryterium nadzoru RIO nad działalnością samorządu terytorialnego w zakresie spraw finansowych jest legalność, czyli oparcie każdego działania na określonych przepisach prawa, które muszą być zgodne z aktualnym

\footnotetext{
1 Dane Regionalnych Izb Obrachunkowych.
} 
stanem prawnym państwa (Zimmermann, 2008: 230). Legalność oznacza zgodność działalności kontrolowanego podmiotu z obowiązującymi regulacjami prawnymi (zwłaszcza ustawowymi).

Do głównych zadań RIO należą:

- kontrola gospodarki finansowej i zamówień publicznych,

- nadzór nad działalnością władz samorządowych w zakresie spraw budżetowych,

- opiniowanie określonych działań i aktów samorządowych,

- prowadzenie działalności informacyjnej i szkoleniowej.

\section{Funkcje Regionalnych Izb Obrachunkowych i wyniki ich działalności}

RIO prowadzi kontrolę w szerokim zakresie zagadnień związanych z prowadzeniem gospodarki finansowej i udzielaniem zamówień publicznych jst oraz ich jednostek organizacyjnych. Kontrola zawsze jest prowadzona z zastosowaniem kryteriów legalności oraz zgodności dokumentacji ze stanem faktycznym.

Zakres kontroli kompleksowych prowadzonych przez Regionalne Izby Obrachunkowe każdego roku jest podobny, jednolity i obejmuje następujące zagadnienia:

1) ustalenia ogólnoorganizacyjne, $w$ tym wewnętrzne regulacje organizacyjno-prawne,

2) księgowość i sprawozdawczość, w tym gospodarkę pieniężną i kontrolę kasy oraz inwentaryzację,

3) budżet jednostki samorządu terytorialnego, w szczególności:

- dochody budżetowe, $w$ tym subwencje i dotacje, dochody z tytułu podatków i opłat, dochody z majątku,

- wydatki budżetowe $\mathrm{z}$ uwzględnieniem przepisów o zamówieniach publicznych, w tym wydatki bieżące i majątkowe oraz rozliczenie otrzymanych i udzielonych dotacji,

- dług publiczny, przychody i rozchody budżetu.

4) gospodarkę mieniem komunalnym i Skarbu Państwa,

5) rozliczenia jednostki samorządu terytorialnego z jednostkami organizacyjnymi.

Przygotowane wyniki kontroli są podstawą do utworzenia przez izbę wystąpienia pokontrolnego, które kierowane jest następnie do kontrolowanej jednostki. RIO wskazują w nim przyczyny nieprawidłowości, ich kształt, osoby za nie odpowiedzialne oraz wnioski, które mają je zniwelować i polepszyć działalność jednostki (RIO jako organ..., 2018).

Z analizy działalności kontrolnej RIO, która jest przedstawiona w tabeli 1, wynika, że liczba prowadzonych kontroli z roku na rok jest na podobnym poziomie (z niewielką 
tendencją do obniżania - w 2016 r. było o 17 kontroli mniej niż w 2001 r.). Ważnym wskaźnikiem w działalności kontrolnej izb jest liczba stwierdzonych nieprawidłowości. W 2002 r. nastąpiło nagłe zwiększenie przypadków wystąpienia nieprawidłowości o 67,3 proc. w porównaniu z poprzednim rokiem. W następnych latach, jak można zaobserwować na rysunku 1, wystąpiła tendencja do stopniowego zmniejszania się liczby błędów popełnianych przez jednostki poddane kontroli.

Tabela 1. Wyniki działalności kontrolnej RIO

\begin{tabular}{|l|c|c|c|c|c|c|c|}
\hline \multirow{2}{*}{ Działalność kontrolna } & \multicolumn{7}{|c|}{ Lata } \\
\cline { 2 - 9 } & 2001 & 2011 & 2012 & 2013 & 2014 & 2015 & 2016 \\
\hline Ogółem & 1316 & 1387 & 1352 & 1292 & 1260 & 1281 & 1299 \\
\hline $\begin{array}{l}\text { Liczba nieprawidłowości } \\
\text { stwierdzonych w wyniku kontroli }\end{array}$ & 14471 & 15819 & 15930 & 14277 & 14035 & 14156 & 14029 \\
\hline Wymmiar finansowy w mIn PLN & $\mathrm{b} / \mathrm{d}$ & 4902,2 & 4689,6 & 14267,6 & 32849,9 & 7404,8 & 8183,6 \\
\hline
\end{tabular}

Źródło: opracowanie własne na podstawie sprawozdań z działalności RIO i wykonania budżetu przez jst w latach 2001, 2011-2016.

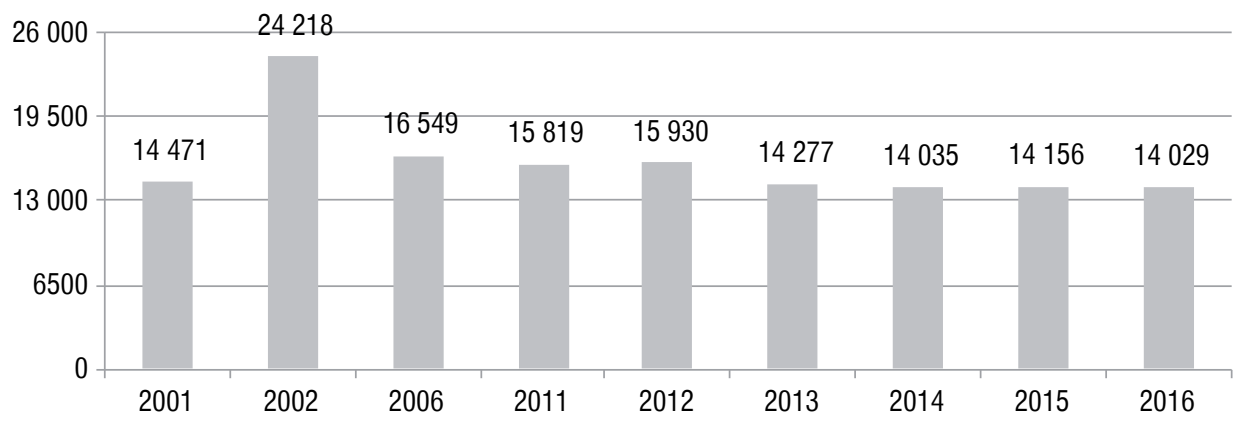

Rysunek 1. Liczba nieprawidłowości stwierdzonych w wyniku kontroli RIO

Źródło: opracowanie własne na podstawie sprawozdań z działalności RIO i wykonania budżetu przez jst w latach 2001, 2011-2016.

Zakres działalności nadzorczej RIO obejmuje uchwały oraz zarządzenia podejmowane przez organy jednostek samorządu terytorialnego w sprawach dotyczących:

1) procedury uchwalania budżetu i jego zmian,

2) budżetu i jego zmian,

3) zaciągania zobowiązań wpływających na wysokość długu publicznego jednostki samorządu terytorialnego oraz udzielania pożyczek,

4) zasad i zakresu przyznawania dotacji z budżetu jednostki samorządu terytorialnego,

5) podatków i opłat lokalnych, do których mają zastosowanie przepisy ustawy, 
6) absolutorium,

7) wieloletniej prognozy finansowej i jej zmian (Ustawa... 1992, 2016).

W wyniku postępowania nadzorczego kolegium RIO orzeka o nieważności uchwał i zarządzeń sprzecznych z prawem. W przypadku, kiedy naruszenie jest nieistotne, ogranicza się do wskazania, że uchwała bądź zarządzenie zostały podjęte $\mathrm{z}$ naruszeniem prawa.

Szczególny tryb postępowania dotyczy stwierdzenia nieważności całości lub części uchwały budżetowej. Jeżeli w takim razie wskazane przez RIO nieprawidłowości nie zostaną usunięte $\mathrm{w}$ wyznaczonym terminie, kolegium RIO orzeka o nieważności uchwały w części lub całości i ustala budżet lub jego nieważną część (Sprawozdania $z$ działalności..., 2016: 28).

Zgodnie z ustawą o finansach publicznych, jeśli organ stanowiący jst nie uchwali budżetu rocznego do dnia 31 stycznia roku budżetowego, to RIO powinny ustalić dla takiej jednostki samorządowej budżet w zakresie zadań własnych oraz zadań zleconych (Ustawa... 2009, 2013). W ten sposób RIO chroni jst przed nieprawidłową działalnością i ryzykiem niewykonania ich zadań w przyszłości (w następnym roku budżetowym). To upoważnienie RIO można uznać za element ostrzegający władze jst.

Analizując działalność nadzorczą RIO trzeba powiedzieć, że liczba zbadanych uchwał i zarządzeń organów samorządowych oraz związków komunalnych z roku na rok rośnie (w 1993 r. wskaźnik ten wynosił 14 105, w 2001 r. - 110 729, w 2011 r. - 163 767, a w 2016 r. - 172 815) (Sprawozdania z działalności..., 2016).

Wyniki badań nadzorczych RIO dają pozytywny efekt. Rezultaty działalności nadzorczej izb zaprezentowano na rysunku 2. W okresie od 1993 do 2016 r. liczba zbadanych uchwał i zarządzeń jst podjętych bez naruszenia prawa wzrosła z 73,1 proc. do 97,7 proc. Można jednak zauważyć, że intensywność tego procesu jest powolna, szczególnie w ostatnich latach. W ciągu sześciu lat (od 2011 do 2016 r.) liczba zgodnych z prawem uchwał i zarządzeń jst waha się, osiąga średnio 97 proc. Tak wysoki poziom prawidłowości działalności jst po nadzorczym badaniu RIO jest jeszcze bardziej imponujący, gdy uwzględnimy dynamikę obniżenia liczby zbadanych uchwał i zarządzeń jst podjętych z naruszeniem prawa. Liczba takich dokumentów w 2016 r. spadła o 24,6 proc. w porównaniu do 1993 r. oraz, i jest to ważne, co roku wskaźnik ten się zmniejsza. Świadczy to o pozytywnej dynamice spadku uchwał i zarządzeń jst podjętych z naruszeniem prawa, choć nadal zaobserwowano lekkie wahania w 2013 r. i 2015 r. 


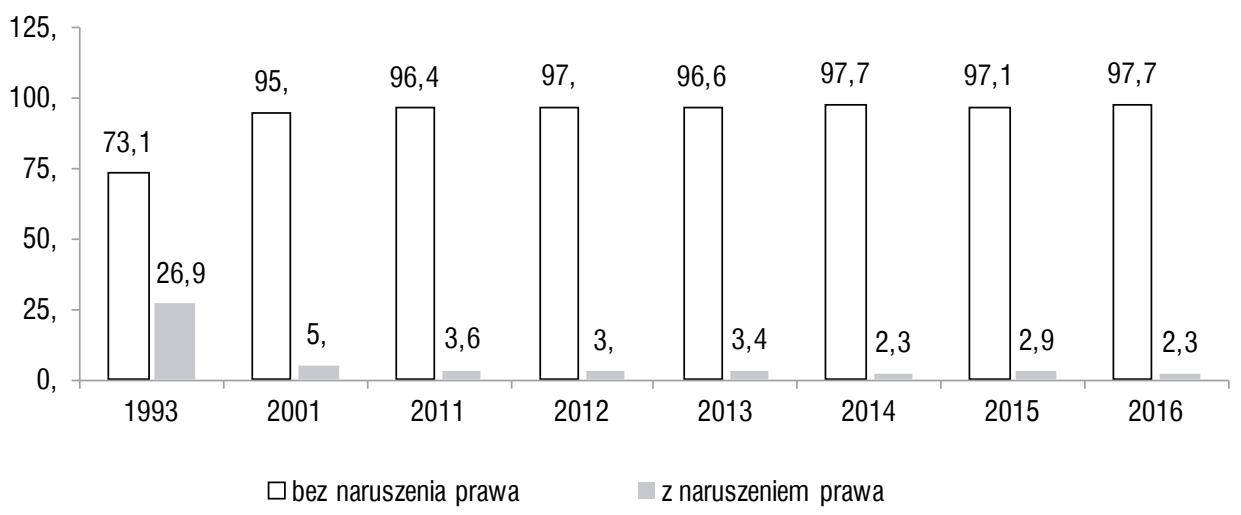

\section{Rysunek 2. Wyniki badania nadzorczego uchwał i zarządzeń jst oraz związków komunalnych (w proc.)}

Źródło: opracowanie własne na podstawie sprawozdań z działalności RIO i wykonania budżetu przez jst w latach 2001, 2011-2016.

Działalność opiniodawcza RIO dotyczy wydawania opinii w sprawach określonych w ustawach. RIO wydaje opinie w sprawach dotyczących:

1) możliwości spłaty kredytu, pożyczki lub wykupu papierów wartościowych, przedkładanych projektów uchwał budżetowych jst,

2) przedkładanych informacji o przebiegu wykonania budżetu za pierwsze półrocze,

3) przedkładanych sprawozdań $z$ wykonania budżetu wraz z informacjami o stanie mienia i objaśnieniami,

4) wniosków komisji rewizyjnych organów stanowiących jst w sprawie absolutorium oraz opinii w sprawie uchwały rady gminy o nieudzieleniu wójtowi absolutorium,

5) przedkładanych projektów uchwał o wieloletnich prognozach finansowych,

6) programów postępowań naprawczych jst,

7) prawidłowości planowanej kwoty długu jst,

8) możliwości sfinansowania deficytu, przedstawionego przez jst w projekcie uchwały budżetowej i odpowiednio w uchwale budżetowej (Ustawa... 1992, 2016).

Opinia jest formą wyrażenia stanowiska przez uprawniony organ, który dokonuje nie tylko oceny formalnej zgodności przedstawionych do zaopiniowania dokumentów z normami prawnymi określającymi ich formę, zakres, szczegółowość oraz wymogi spójności, kompletności i rzetelności danych planistycznych i sprawozdawczych, lecz również oceny legalności działań podejmowanych przez organy jst w realizacji procesów finansów publicznych, w tym oceny ich wpływu na aktualny i przyszły stan ich finansów (Sprawozdania z działalności... w 2015 roku, 2016).

Co ważnie, opinia nie jest aktem nadzoru, a wyrażone w niej stanowisko nie ma charakteru obligatoryjnego dla jej odbiorcy. Opinie poza wyrażeniem stanowiska muszą 
zawierać również jego uzasadnienie. Takie opinie mają pozytywny wpływ na działalność jst. Dotyczy to szczególnie uchwały budżetowej, której podjęcie musi być poprzedzone przedstawieniem organowi stanowiącemu jst opinii regionalnej izby obrachunkowej o projekcie uchwały budżetowej (Ustawa... 2009, 2013). W wypadku negatywnej opinii o projekcie budżetu RIO wskazują nieprawidłowości organom stanowiącym. Jeśli adresat opinii zrezygnuje z uwag w niej zawartych, to w późniejszym okresie może to skutkować ingerencją nadzorczą RIO, która ma prawo uznać uchwałę budżetową za nieważną.

Ranga i znaczenie opinii przejawia się w tym, że pochodzą one od organów zewnętrznych wyspecjalizowanych w kontroli gospodarki finansowej jst, które poza tym posiadają odpowiednie materiały źródłowe i stosowną wiedzę, aby wypowiedzieć się kompetentnie w sprawach będących przedmiotem opinii. Stanowisko zawarte w opinii powinno zawierać obiektywną i rzetelną ocenę danego rodzaju sprawy. Opinie odnoszą się głównie do projektowanych rozstrzygnięć organów jst. Stąd ich znaczenie dla tworzenia zgodnych z prawem norm prowadzenia gospodarki finansowej przez te jednostki (Szołno-Koguc, 2011: 674).

Wynikiem tych ocen jest wydanie przez skład orzekający opinii pozytywnej lub negatywnej, a w razie konieczności zasygnalizowania nieprawidłowości i uchybień - opinii pozytywnej z uwagami lub zastrzeżeniami. Trzeba pamiętać, że wszystkie opinie RIO wydawane są na podstawie kryterium legalności.

Liczba wydanych opinii w ciągu ostatnich sześciu lat jest podobna, choć obniża się nieco w ostatnich dwóch latach (w 1993 r. wskaźnik ten wynosił 4030, w $2001 \mathrm{r}$. - 18 435, w 2011 r. - 27 791, w 2013 r. - 25 538, w 2016 r. - 23 718). Ważne jest to, że wydanie opinii w sprawach dotyczących budżetu i działalności gospodarczej jst w ogóle wzrosło sześciokrotnie w porównaniu z 1993 r. i 1,3 raza w porównaniu z 2001 r., co świadczy o tym, że uczestnictwo RIO w działalności organów samorządowych znacznie się zwiększyło. Tymczasem poziom liczby wydanych opinii pozytywnych jest prawie niezmienny od ponad 10 lat, z kilkoma nieistotnymi wahaniami, które łatwo zauważyć na rysunku 3. Poziom pozytywnych opinii w 2016 r. wzrósł o 9,2 proc. w porównaniu z 1993 r. W okresie od 2014 r. do 2016 r. również występuje tendencja do zwiększania się liczby pozytywnych opinii. Związane jest to $\mathrm{z}$ obniżeniem w tych latach liczby wydanych opinii pozytywnych z uwagami. I tak - w porównaniu z 2013 r., kiedy poziom ten wynosił 17,9 proc. (taki sam był w $2001 \mathrm{r}$.) - w 2014 r. odsetek tych opinii spadł o 2 proc., w 2015 r., - o 4,8 proc., a w 2016 r. - o 6,1 proc. W odniesieniu do negatywnych opinii wydanych przez RIO można zobaczyć, że w ciągu sześciu lat (od 2011 do 2016 r.), z wyjątkiem 2012 r., występuje zmniejszenie tego wskaźnika. Ogólnie wyniki działalności opiniodawczej RIO są bardzo podobne w poszczególnych latach, ale w ostatnich latach wzrasta liczba pozytywnych opinii. 


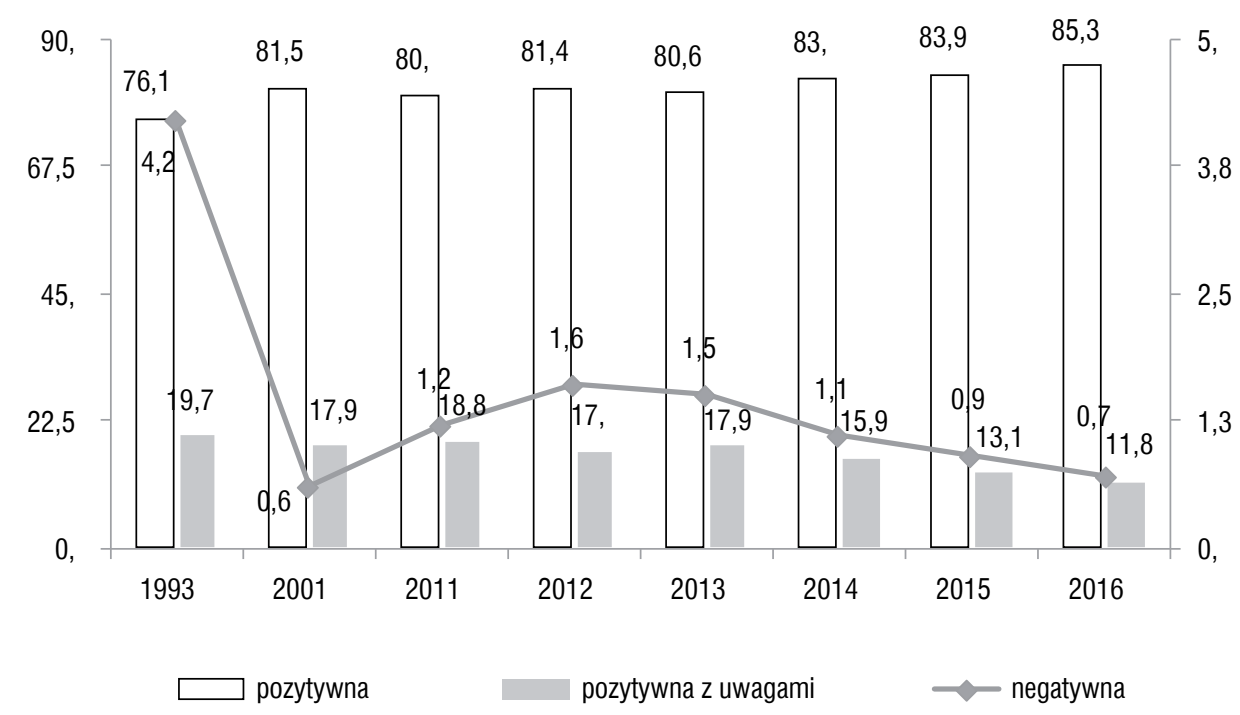

Rysunek 3. Charakter wydanych opinii (w proc.)

Źródło: opracowanie własne na podstawie sprawozdań z działalności RIO i wykonania budżetu przez jst w latach 2001, 2011-2016.

Działalność informacyjna i szkoleniowa prowadzona przez RIO jest realizowana w zakresie objętym nadzorem i kontrolą RIO. Ma pośredni wpływ na nadzór i kontrolę nad jst. Przez prowadzone szkolenia, seminaria czy wydawane materiały informacyjne RIO zwiększa wiedzę i profesjonalizm pracowników jst, co w rezultacie zmniejsza ilość błędów w prowadzonej przez jst działalności finansowej (budżetowej) i wpływa na polepszenie jakości funkcjonowania organów samorządowych z punktu widzenia legalności.

Izby zobowiązane są do udzielania wyjaśnień w sprawach dotyczących stosowania przepisów o finansach publicznych (Ustawa... 1992, 2016). Jednak zakres wyjaśnień jest szerszy i jest związany z szeroko rozumianą gospodarką finansową jst, a zwłaszcza $\mathrm{z}$ innymi regulacjami ustawowymi, które mają bezpośredni wpływ na poziom dochodów, wydatków i zobowiązań prezentowanych w budżetach jst (Sprawozdania z działalności... w 2015 roku, 2016: 127-130).

Pozytywna tendencja wzrostu uchwałi zarządzeń podjętych bez naruszania prawa oraz pozytywnych opinii RIO i zmniejszenia się nieprawidłowości może być jednym z wyników prowadzonych szkoleń, wydawanych pisemnych odpowiedzi na pytania dotyczące różnych aspektów działalności finansowej jst, jak również udostępniania informacji w środkach masowego przekazu. Ponadto, jak uważają politycy, działalność szkoleniowa i informacyjna nie powinna być dodatkową funkcją izb, a powinna 
stanowić możliwość wspierania i instruowania samorządów terytorialnych (NIK chwali RIO, 2018).

Podsumowując przedstawiony powyżej zakres działalności RIO i pozytywne tendencje w podwyższeniu kultury prawnej w funkcjonowaniu jednostek samorządu terytorialnego, można stwierdzić, że RIO stanowi ważny element nadzoru nad samorządem terytorialnym przyczyniający się do podniesienia jakości stanowienia prawa przez organy jednostek samorządu terytorialnego, ponieważ eliminuje z obrotu prawnego uchwały i zarządzenia podjęte z naruszeniem prawa (Narowska, Pańczyk i Szybowska, 2012: 111). Jednak mając prawo do orzekania nieważności uchwał podjętych przez władze samorządowe w przypadku ich niezgodności z prawem, do wstrzymania ich wykonania oraz do wskazania uchybień przy nieistotnych naruszaniach prawa, RIO jako organ nadzorczy i kontrolujący ma znaczny wpływ na działalność jednostek samorządu terytorialnego.

\section{Czy działanie organu nadzoru i kontroli nad gospodarką finansową jst powoduje ograniczenia ich samodzielności finansowej?}

Nadzór zawsze oznacza możliwość władczej ingerencji w działalność organów samorządu terytorialnego. Nadmierne wkraczanie w ich aktywność może w efekcie prowadzić do ograniczenia samodzielności jst. Dlatego, w celu zapobiegania złemu wpływowi nadzoru nad organami samorządowymi, ustanowiona została sądowa ochrona niezależnego wykonywania władztwa samorządu terytorialnego.

I tak orzeczenie RIO może podlegać zaskarżeniu do sądu administracyjnego w sytuacji, kiedy samorząd nie zgadza się z interpretacją prawa zastosowaną przez organ nadzoru. Natomiast do sądu administracyjnego jst nie może zaskarżyć takich orzeczeń RIO, w których wskazano, że akt jst narusza prawo w sposób nieistotny. W związku z tym, że z zestawienia w tabeli 2 wynika, iż takiego rodzaju naruszeń jest niemal tyle samo, co skutkujących uznaniem za nieważne, można uznać, że to stanowi istotne ograniczenie samodzielności finansowej jst.

Oprócz tego przepisy nie przewidują szczególnych preferencji w postaci szybkiej ścieżki w sądzie administracyjnym w wypadku rozpatrywania skargi jst na rozstrzygnięcie nadzorcze (poza rozstrzygnięciami o nieważności uchwały budżetowej). Odległe terminy rozpraw przed sądem administracyjnym zniechęcają jst do korzystania $\mathrm{z}$ instytucji sądowej ochrony samodzielności finansowej (Narastające dysfunkcje..., 2013: 27). 
Tabela 2. Wyniki badania nadzorczego w zakresie uchwał i zarządzeń podjętych z naruszeniem prawa w latach 2010-2016

\begin{tabular}{|l|c|c|c|c|c|c|c|}
\hline \multirow{2}{*}{$\begin{array}{c}\text { Uchwały z naruszeniem } \\
\text { prawa }\end{array}$} & \multicolumn{7}{|c|}{ Lata } \\
\cline { 2 - 8 } & 2010 & 2011 & 2012 & 2013 & 2014 & 2015 & 2016 \\
\hline Ogótem & 4725 & 5877 & 4812 & 5586 & 3862 & 5199 & 4050 \\
\hline \multirow{2}{*}{ Nieistotne naruszenie prawa } & 1385 & 2264 & 1883 & 2015 & 1137 & 1335 & 1285 \\
& $(0,9 \%)$ & $(1,4 \%)$ & $(1,2 \%)$ & $(1,2 \%)$ & $(0,7 \%)$ & $(0,7 \%)$ & $(0,7 \%)$ \\
\hline \multirow{2}{*}{ Uznane za nieważne } & 1742 & 1842 & 1570 & 2091 & 1566 & 2394 & 1739 \\
& $(1,2 \%)$ & $(1,1 \%)$ & $(1,0 \%)$ & $(1,3 \%)$ & $(0,9 \%)$ & $(1,3 \%)$ & $(1,0 \%)$ \\
\hline
\end{tabular}

Źródło: opracowanie własne na podstawie sprawozdań z działalności RIO i wykonania budżetu przez jst w latach 2010-2016.

Niektóre decyzje podjęte przez RIO mogą być niezgodne z logiką racjonalnego gospodarowania, chociaż spełniają kryterium legalności. Tak np. ustawa o systemie oświaty nakłada na gminę dokładnie sparametryzowane zadania obowiązkowe w zakresie dowozu uczniów do szkół. Według orzecznictwa RIO gmina „nie może” (a według sądów administracyjnych „nie musi”) dowozić uczniów, którzy mieszkają w odległości bliższej od szkoły, niż jest to przewidywane w przepisach. W konsekwencji, gdy miejsce zamieszkania dzieci z jednej i tej samej rodziny zlokalizowane jest w odległości od 3 do $4 \mathrm{~km}$ od szkoły podstawowej, to dzieci uczęszczające do klas I-IV są dowożone, a ich rodzeństwo z klas V i VI nie może korzystać z organizowanego przez gminę dowozu uczniów do szkoły podstawowej (Ibidem: 21). Jednak taka sytuacja bierze się z tego, że RIO w swojej działalności kierują się tylko i wyłącznie kryterium legalności, dlatego określona kolizja jest wynikiem niedoskonałości przepisów prawnych.

Wskazane wady w działalności RIO, które ograniczają samodzielność finansową jst, mają charakter prawny oraz proceduralny. Jednak istnieją inne, mniej widoczne wady, które negatywnie oddziałują na jst.

Prowadzona kontrola i nadzór dotyczą tylko aktualnego stanu jednostek samorządowych i nie biorą pod uwagę podejścia strategicznego w podejmowaniu decyzji o wydatkach na rozwój miejscowości. Taki charakter mają interwencje organów nadzoru i kontroli związane z decyzjami rozwojowymi samorządu, a interwencje często nie uwzględniają długofalowych kalkulacji strategicznych oraz prawa do ryzyka, którego nie da się wyeliminować przy podejmowaniu decyzji strategicznych w niestabilnych warunkach ekonomicznych. Działania takie budzą obawy lokalnych władz i powstrzymują je przed realizowaniem ambitnych przedsięwzięć rozwojowych, a w wielu przypadkach są niezgodne nie tylko z duchem Konstytucji, ale także z logiką racjonalnego gospodarowania (Ibidem: 20). Przecież ryzyko oraz niestabilność ekonomiczna będą istniały zawsze, bo są warunkami ekonomicznymi 
systemu gospodarczego, jednak ważne jest, aby doceniać zyski, które można osiągnąć w przyszłości i które pokryją poniesione dziś straty. Oczywiście takie wydatki (najczęściej inwestycyjne) w bliskiej perspektywie (bieżący rok budżetowy i następny) wydają się nieracjonalne i mogą przekraczać próg pozyskiwania środków zewnętrznych oraz poziom zadłużenia, a wtedy RIO może orzekać o nieprawidłowości takich decyzji władz samorządowych. Jednak w dłuższej perspektywie te wydatki budżetowe przyniosą więcej zysków dla rozwoju terenu i poprawienia jakości świadczenia usług publicznych mieszkańcom.

Dlatego nadzór i kontrolę nad takimi wydatkami należy prowadzić w szerszej perspektywie, żeby nie zniechęcić jst do inicjatywy rozwoju danego obszaru, podejmowania ryzyka oraz strategicznego patrzenia na teren, którym zarządza samorząd.

Ponadto, decyzje podejmowane przez jst dotyczące wydatków finansów publicznych również wymagają szerszego podejścia w zakresie terytorialnym. Władze samorządowe powinny zajmować się rozwojem swojego terenu, jednak równie ważnym elementem tego procesu jest spojrzenie na sąsiadów, a nawet na cały region. Gminy mają prawo do samodzielnego zarządzania (np. podejmowania decyzji dotyczących rozwoju, zmiany infrastruktury, budownictwa) na własnym terenie działalności gospodarczej oraz do samodzielności finansowej, która umożliwia samodzielne wydawanie środków na wyznaczone cele. Jednak nie zawsze cele te są uzasadnione z punktu widzenia racjonalności i adekwatności, a potrzeba, na spełnienie której powinny być wydane środki, niekoniecznie jest właściwa dla danego obszaru.

Zasada adekwatności wymaga, aby środki finansowe przeznaczone dla wspólnot lokalnych uwzględniały zróżnicowany zakres zadań w różnych rodzajach jednostek ze względu na ich specyfikę w stosunku do pozostałych. I taka adekwatność środków do zadań może być także traktowana jako jedna z gwarancji samodzielności finansowej samorządu (Kornberger-Sokołowska, 2015: 57-69).

Decyzje o wydaniu środków finansowych nieuwzględniające ich adekwatności największy ubytek przynoszą tam, gdzie jest potrzebne duże finansowanie. Tak np. władze miasta Gdyni rozpoczęły finansowanie budowy portu lotniczego w gminie Kosakowo za środki unijne na kwotę 85,5 mln PLN. Jednak ze względu na to, że w odległości 31 km od Kosakowa leży inny port lotniczy - Gdańsk Rębiechowo, który z powodzeniem może obsługiwać całe Trójmiasto - Komisja Europejska wyraziła wątpliwości, czy budowa lotniska w Gdyni jest zasadna i nakazała zwrot funduszy pomocy publicznej (Katka, 2016).

Innym przykładem jest budowa drogi w województwie dolnośląskim. Miasto Wrocław i gmina Kobierzyce nie potrafiły dojść do konsensusu i zamiast wybudowania wspólnej drogi, każdy zbudował własną. Dwie biegnące obok siebie drogi są podzielone wąskim pasem ze słupkami drogowymi, co sprawia, że robią się jeszcze 
węższe, a dodatkowo nie mają skrzyżowania. Ważne jest to, że wybudowanie drugiej drogi było wykonaniem planu miejscowego zagospodarowania przez władze gminy. Władze miasta oraz władze gminy nie były w stanie skoordynować działania w celu powstania jednej wspólnej drogi, która byłaby wygodna dla mieszkańców danej miejscowości (Rosa, 2017).

Te przykłady pokazują nieadekwatność gospodarowania i dystrybucji kosztów przez władze. I chociaż takie nieracjonalne zarządzanie finansami publicznymi nie przeczy ustawodawstwu, to jest stratą środków (czas, zasoby ludzkie, pieniężne), które mogłyby zostać użyte na zaspokojenie aktualnych i realnych potrzeb mieszkańców danej jednostki samorządu terytorialnego. Dlatego wydaje się potrzebne poszerzenie funkcji RIO na płaszczyznę kontroli racjonalności wydawania finansów publicznych jst z perspektywy sąsiedzkiej, żeby mogły one ostrzegać przed marnotrawstwem ze strony władz samorządowych.

Innym negatywnym aspektem nadzoru prowadzonego nad sprawami finansowymi jst jest ograniczanie ich odpowiedzialności. Ponieważ odpowiedzialność za decyzję co do jej prawidłowości i legalności bierze na siebie organ nadzoru, zmniejsza się rzetelność zarządzania sprawami finansowymi - szczególnie budżetowymi - i zamówieniami publicznymi przez jst, bowiem w razie wystąpienia ewentualnego problemu władze jednostki samorządowej często przyjmują, że RIO zdoła wszystko naprawić. Taka sytuacja obniża w rezultacie aktywność jst w podejmowaniu uchwał przez organy samorządowe.

Tendencję tę można zaobserwować przy analizie zmian w ciągu kilku lat dotyczących uchwalania budżetu przez jst. Zgodnie z ustawą o finansach publicznych (Ustawa... 2009, 2013) organ wykonawczy jst przedkłada projekt uchwały budżetowej RIO dla zaopiniowania do dnia 15 listopada roku poprzedzającego rok budżetowy. Ogólna tendencja jest taka, że odsetek jst, które w ustawowym terminie przedłożyły regionalnym izbom obrachunkowym projekty uchwał budżetowych w latach 20102016 rośnie. Jednak w ostatnich latach wzrost ten był powolny (mniej niż 1 proc.), nawet $\mathrm{z}$ niewielkim obniżeniem w 2015 r., co widać na rysunku 4. Znaczny postęp w tym kierunku nastąpił w 2016 r. (odsetek przekładanych projektów po 15 listopada był o 6,7 proc. niższy).

Inaczej wygląda sytuacja budżetów uchwalonych przez organy samorządowe, zaprezentowana na rysunku 5. Zgodnie z art. 239 ustawy o finansach publicznych organ stanowiący jst podejmuje uchwałę budżetową przed rozpoczęciem roku budżetowego (do 31 grudnia), a w szczególnych przypadkach nie później niż do dnia 31 stycznia roku budżetowego. Do czasu podjęcia uchwały budżetowej, jednak nie później niż do dnia 31 stycznia roku budżetowego, podstawą gospodarki finansowej jest projekt uchwały budżetowej przedstawiony organowi stanowiącemu 
jst. W niektórych wypadkach określonych prawnie (Ustawa...2013, 2013) jst, które przekroczyły terminy uchwały budżetowej, jeśli opracowały program postępowania naprawczego i uzyskały pozytywną opinię RIO, otrzymały możliwość uchwalenia budżetu po 31 stycznia roku budżetowego.

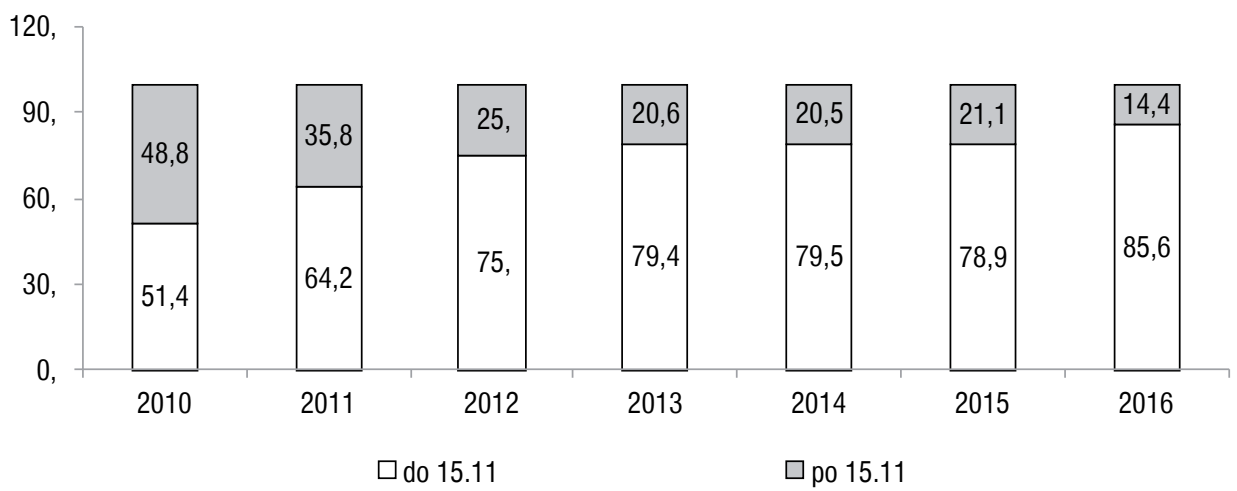

\section{Rysunek 4. Terminy przedkładania projektów budżetów przez organy samorządowe w latach 2010-2016 (w proc.)}

Źródło: opracowanie własne na podstawie sprawozdań z działalności RIO i wykonania budżetu przez jst w latach 2010-2016.

W latach 2010-2016 liczba budżetów uchwalonych w jst do 31 grudnia jest zróżnicowana. W 2011 r. nastąpił gwałtowny ich spadek o 28,1 proc. W latach 2012-2014 trend się odwrócił, a liczba budżetów uchwalonych przez jst stopniowo się zwiększała i przekroczyła poziom z $2010 \mathrm{r}$. Jednak pozytywna tendencja w $2015 \mathrm{r}$. zatrzymała się i znowu nastąpił spadek liczby uchwalonych budżetów (o 20,9 proc. w porównaniu z 2014 r.), aby w 2016 r. osiągnąć poziom z 2014 r. Odwrotne tendencje wystąpiły w budżetach uchwalonych do 31 stycznia, gdzie najmniej takich przypadków było w 2014 r. i 2016 r. (16,3 proc. i 16,4 proc.), a najwięcej w 2011 r. (63,1 proc.).

Jeszcze ważniejszym wskaźnikiem jakości działania organów samorządowych jest liczba przypadków, w których samorządy nie potrafiły uchwalić budżetu zgodnie z prawem (w tym przypadki nieopracowania programu postępowania naprawczego lub braku pozytywnej opinii RIO) i budżet został ustalony przez Regionalne Izby Obrachunkowe. W ciągu trzech lat (2011-2014) ten wskaźnik był na jednym poziomie (5 budżetów), z tendencją wzrostu w 2014 r. (11 budżetów) oraz w 2015 r. (16 budżetów) i obniżeniem do 10 takich budżetów w $2016 \mathrm{r}$. 


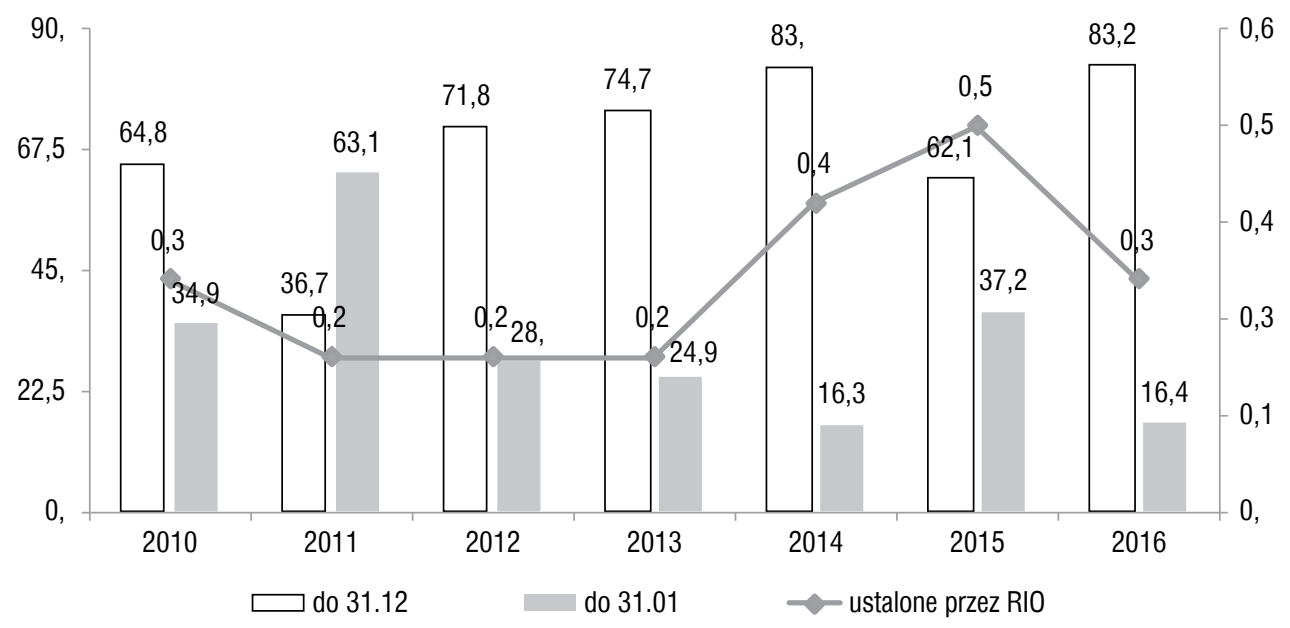

Rysunek 5. Odsetek uchwalonych budżetów przez jst w latach 2010-2016 (w proc.)

Źródło: opracowanie własne na podstawie sprawozdań z działalności RIO i wykonania budżetu przez jst w latach 2010-2016.

Tak więc na tle ogólnej pozytywnej tendencji do zwiększenia kultury prawnej w działalności organów samorządowych, spadku ilości błędów i naruszeń prawa, można zauważyć, że proces ten nie jest stabilny, co w pewnym stopniu świadczy o poziomie rzetelności i odpowiedzialności budżetowej organów jst. Prowadzenie nadzoru i kontroli na wysokim poziomie przez RIO gwarantuje z jednej strony jednostkom samorządowym uchwalanie budżetów zgodnie z prawem (co daje im pewne poczucie bezpieczeństwa, a w konsekwencji obniża ich aktywność), z drugiej zaś strony ogranicza ich samodzielność.

Podsumowując powyższą analizę należy stwierdzić, że działalność regionalnych izb obrachunkowych nie przeczy idei samorządności. Ponadto RIO, jako jedna z głównych instytucji w obszarze kontroli i nadzoru finansowego państwa, odgrywają ważną rolę $\mathrm{w}$ realizacji procesu decentralizacji władzy. Zapewniają one przestrzeganie przepisów dotyczących planowania i przeprowadzania polityki finansowej (budżetowej) jst. Działalność RIO w ciągu ponad 20 lat doprowadziła do znacznego wzrostu poziomu legalności przyjętych przez jednostki samorządu terytorialnego uchwał i zarządzeń, do stałego zmniejszania nieprawidłowości w ich działalności oraz do poprawienia jakości kultury prawnej. Oprócz tego działalność RIO ma bardzo szeroki zakres, nie ogranicza się tylko do interwencji w działalność jst - RIO wydają również opinie i udzielają informacji, realizują szkolenia, co w efekcie prowadzi do kształtowania nowych jakościowo norm zachowania jst. 
Niewątpliwie zauważalne jest jednak nieracjonalne gospodarowanie czy nierozsądne dysponowanie środkami pieniężnymi władz samorządowych, co w konsekwencji prowadzi do zagrożenia wykonywania zadań publicznych. Jednostki samorządu terytorialnego mogą wykorzystywać środki na niewłaściwe wydatki (usługi, produkty) bez zważania na specyfikę terenu albo na podmioty, które wykonują podobną funkcję $\mathrm{w}$ granicach danej jst. Taka sytuacja często jest uzasadniona brakiem porozumienia między władzami sąsiednich jednostek. RIO potrafią zauważyć nieefektywne oraz nierozważne stosowanie środków, analizując sprawozdania organów samorządowych. Nie mają one jednak prawa do zapobiegania takiej działalności, ponieważ nie stoi ona w sprzeczności z kryterium legalności, gdy jest wykonywana odpowiednio do planu budżetowego. Nieracjonalne gospodarowanie stanowi istotne zagrożenie zwiększenia długu w przyszłości oraz obniżenia samodzielności finansowej jst.

Dlatego istnieje potrzeba rozszerzenia kryteriów, na podstawie których RIO prowadzą nadzór i kontrolę nad działalnością samorządu terytorialnego w zakresie spraw finansowych poprzez dopełnienie kryterium legalności kryterium adekwatności. To umożliwi RIO wpływanie na racjonalizowanie działalności jst. Potrzebne wydają się też inne zmiany prawne: przede wszystkim ułatwienie władzom samorządowym zaskarżania orzeczeń RIO w sądzie administracyjnym, podniesienie aktywności jst, zainteresowanie ich jak najlepszym przestrzeganiem uchwał prawnych oraz wykonaniem przepisów dotyczących przedkładania projektów budżetowych i budżetów w ustalonym terminie.

\section{Bibiliografia}

Antkowiak, P. (2011). Decentralizacja władzy publicznej w Polsce na przykładzie samorządu terytorialnego. Środkowoeuropejskie Studia Polityczne, $\mathrm{nr} 2$.

Katka K. (2016). Jak Gdynia budowała lotnisko w Kosakowie. Jest raport NIK. Gazeta Wybor$c z a, 21.01 .2016$.

Konstytucja Rzeczypospolitej Polskiej z dnia 2 kwietnia 1997 r., Dz. U. 1997, nr 78, poz. 483.

Kornberger-Sokołowska, E. (2001). Realizacja zasady adekwatności w procesach decentralizacji finansów publicznych. Samorząd Terytorialny, nr 3.

Kornberger-Sokołowska, E. (2015). Zasada adekwatności, w: Itrich-Drabarek, J., Borowska, E., Morawski, A. i Przastek, D. (red.). Samorzad terytorialny w Polsce - reforma czy kontynuacja?. Warszawa: Dom Wydawniczy Elipsa.

Narastajace dysfunkcje, zasadnicze dylematy, konieczne działania. Prezentacja raportu o stanie samorząności terytorialnej w Polsce (2013). Kraków. 
Narowska, A., Pańczyk, M. i Szybowska M. (2012). Nadzór regionalnych izb obrachunkowych nad podstawową jednostką samorządu terytorialnego - zagadnienia wybrane. Acta Universitatis Lodziensis, Folia Oeconomica, nr 270.

Rosa, M. (2017). Co dwie drogi, to nie jedna! Samorządy się nie dogadały, mieszkańcy dostali dwie ulice. Gazeta Wyborcza, 17.08.2017.

Sprawozdania $z$ działalności regionalnych izb obrachunkowych i wykonania budżetu przez jednostki samorzadu terytorialnego w latach 2001, 2011-2016.

Szołno-Koguc, J. i Pomorska, A. (red.) (2011). Ekonomiczne i prawne uwarunkowania i bariery redukcji deficytu i długu publicznego. Warszawa.

Ustawa z dnia 7 października 1992 r. o regionalnych izbach obrachunkowych, Dz. U. 2016, poz. 561.

Ustawa z 23 grudnia 1994 r. o Najwyższej Izbie Kontroli, Dz. U. 2007, nr 231, poz. 1701.

Ustawa z dnia 27 sierpnia 2009 r. o finansach publicznych, Dz. U. 2013, poz. 885.

Ustawa z dnia 8 listopada 2013 r. o zmianie ustawy o finansach publicznych oraz niektórych innych ustaw, Dz. U. 2013, poz. 1646 z późn. zm.

Zimmerman, J. (2008). Prawo administracyjne. Warszawa: Oficyna a Wolters Kluwer business. 